\title{
O Projeto Educativo de Integração Social - PEIS: o curso "Matemática Básica II: As quatro operações e expressões lineares".
}

\author{
Ana Martha Santos Vieira, Bruno Raniere Andrade, Rodrigo Castilho de Almeida, Sandra Fernandes Leite.
}

\begin{abstract}
Resumo
O Projeto Educativo de Integração Social (PEIS) é um espaço de viabilização da formação de educadores (as) para a Modalidade Educação de Jovens e Adultos (EJA) no âmbito da extensão da Unicamp. Através da formação e da pesquisa, os graduandos dos cursos de licenciatura da Unicamp desenvolvem projetos e ações de atuação para educandos jovens, adultos e idosos da comunidade. Este trabalho relata as experiências observadas em um semestre do curso "Matemática Básica II: As quatro operações e expressões lineares" desenvolvido por alunas(os) da licenciatura da Unicamp. Como uma ação de extensão universitária, o curso "Matemática Básica II" promoveu uma revisão de conteúdos básicos da matemática e o aprofundamento aos mesmos. Através de aulas expositivas, tarefas interativas, jogos de tabuleiro e listas de atividades, buscou-se contribuir na visão de mundo das(os) educandas(os) por meio do esclarecimento de conteúdos básicos da matemática.
\end{abstract}

Palavras-chave: Educação de Jovens e Adultos, matemática, extensão universitária.

\section{Introdução}

O Projeto Educativo de Integração Social (PEIS) da Faculdade de Educação da Unicamp trabalha com jovens, adultas(os) e idosas(os) de baixa escolarização e pessoas pertencentes à comunidade, em sua maioria, de baixo poder aquisitivo. O PEIS utiliza as concepções de Paulo Freire e proporciona um espaço de prática e formação para os estudantes de licenciatura da Unicamp. Através de um ambiente interdisciplinar com relações diretas com 0 curso de formação de cada acadêmico, aliam teoria e prática em suas formações. Com base no trabalho entre formação, pesquisa e extensão, os discentes desenvolvem atividades voltadas para prática pedagógica por meio de diferentes propostas de cursos para a comunidade. Este trabalho retrata a experiência do curso "Matemática Básica II: "As quatro operações e expressão linear" oferecido no primeiro semestre de 2017 aos sábados. O curso trata de uma revisão de conteúdos básicos da matemática e de um aprofundamento ao mesmo. Por mais que não tenha por pré-requisito o curso de Matemática Básica I, muito dos conteúdos tratados foram uma continuidade desse primeiro curso oferecido no segundo semestre de 2016. Nesse sentido, o objetivo foi esclarecer conceitos da matemática básica a fim de capacitar as(os) educandos(os) para uma melhor leitura de mundo. A metodologia utilizada consistiu em aulas expositivas, tarefas interativas, jogos de tabuleiro e listas de atividades. Foram trabalhados os seguintes conteúdos: 1) soma; 2) subtração; 3) divisão; 4) multiplicação; 5) fração; 6) expressões lineares. As(os) educandas(os) ainda foram avaliadas(os) de forma individual durante todo o processo do curso através das atividades, presença e desenvolvimento em sala.

\section{Resultados e Discussão}

O Curso "Matemática Básica II" teve a participação de 8 educandos, com idades variando de 40 a 70 anos. Durante o semestre foram propostas aos educandos listas de exercícios, seguindo os conteúdos trabalhados e, para que a avaliação individual e coletiva pudesse ser feita com maior eficiência, cada tarefa foi acompanhada por um questionário onde os alunos puderam avaliar seus próprios rendimentos nos conceitos matemáticos discutidos. Assim, o planejamento dos educadores foi constantemente moldado, baseado nas dificuldades relatadas pelos educandos, a fim de concluir o período do curso com a convicção do avanço de cada um deles, respeitando seus momentos.

\section{Conclusões}

O curso "Matemática Básica II: As quatro operações e expressão linear" proporcionou ao dia a dia dos educandos jovens, adultos e idosos um aprofundamento dos conteúdos matemáticos. O curso teve por finalidade o esclarecimento de conteúdos básicos da matemática, capacitando os alunos para uma melhor leitura de mundo. As aulas expositivas, tarefas interativas, jogos de tabuleiro e listas de atividades, aliadas com a constante modificação dos planejamentos das aulas, foram realizados para promover uma maior fixação dos conteúdos pelos alunos.

\section{Agradecimentos}

Ao Serviço de Apoio ao Estudante SAE/Unicamp pelas bolsas BAS, à PREAC/Unicamp e ao GGBS pelo apoio financeiro e à Faculdade de Educação pelas instalações e laboratórios.

D’AMBRÓSIO, U. Educação Matemática: da teoria à prática. 2. ed Campinas-SP: Papirus, 1997. (Col. Perspectivas em Educação Matemática).

${ }^{2}$ LEITE, S.F. O Direito à Educação Básica para Jovens e Adultos da Modalidade EJA no Brasil: um resgate histórico e legal. Curitiba: CRV, 2013, v.1. p.326.

SOUZA, C. R. P.; LEITE, S. F..Relato de Experiência no Projeto Educativo de Integração Social - PEIS: Uma Alternativa Metodológica para a Educação de Adultos. CD de Textos Completos do GEPEJA, 2010. 